\title{
Multi-year comparison of stratospheric BrO vertical profiles retrieved from SCIAMACHY limb and ground-based UV-visible measurements
}

\author{
F. Hendrick ${ }^{1}$, A. Rozanov ${ }^{2}$, P. V. Johnston ${ }^{3}$, H. Bovensmann ${ }^{2}$, M. De Mazière ${ }^{1}$, C. Fayt ${ }^{1}$, C. Hermans ${ }^{1}$, K. Kreher ${ }^{3}$, \\ W. Lotz ${ }^{2}$, B.-M. Sinnhuber ${ }^{2}$, N. Theys ${ }^{1}$, A. Thomas ${ }^{3}$, J. P. Burrows ${ }^{2}$, and M. Van Roozendael ${ }^{1}$ \\ ${ }^{1}$ Belgian Institute for Space Aeronomy (IASB-BIRA), Brussels, Belgium \\ ${ }^{2}$ Institute for Environmental Physics/Remote Sensing, Univ. of Bremen, Bremen, Germany \\ ${ }^{3}$ National Institute of Water and Atmospheric Research (NIWA), Omakau, Central Otago, New Zealand
}

Received: 14 November 2008 - Published in Atmos. Meas. Tech. Discuss.: 23 December 2008

Revised: 3 June 2009 - Accepted: 11 June 2009 - Published: 19 June 2009

\begin{abstract}
Vertical profiles of stratospheric bromine monoxide $(\mathrm{BrO})$ retrieved daily from ENVISAT/SCIAMACHY (ENVIronmental SATellite/SCanning Imaging Absorption spectroMeter for Atmospheric CHartographY) limb scatter data and from ground-based UV-visible observations performed at Harestua $\left(60^{\circ} \mathrm{N}, 11^{\circ} \mathrm{E}\right)$, Observatoire de HauteProvence $\left(44^{\circ} \mathrm{N}, 5.5^{\circ} \mathrm{E}\right)$, and Lauder $\left(45^{\circ} \mathrm{S}, 170^{\circ} \mathrm{E}\right)$ are compared in the $15-27 \mathrm{~km}$ altitude range for the 2002-2006, 2005-2006, and 2002-2005 periods, respectively. At the three stations, the SCIAMACHY and ground-based UVvisible mean profiles agree reasonably well, with relative difference smaller than $23 \%$. When comparing the $\mathrm{BrO}$ partial columns, the agreement obtained is good, with mean relative differences smaller than $11 \%$ and corresponding standard deviations in the 13-19\% range. These comparison results are obtained, however, using different $\mathrm{BrO}$ cross sections in SCIAMACHY limb and ground-based UV-visible retrievals. The seasonal variation of the $\mathrm{BrO}$ columns at the three stations is consistently captured by both retrievals as well as large $\mathrm{BrO}$ column events occurring during the winter and early spring at Harestua which are associated with bromine activation.
\end{abstract}

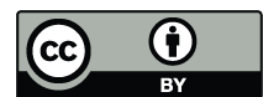

Correspondence to: F. Hendrick (franch@oma.be)

\section{Introduction}

Owing to their global spatial and temporal coverage, spaceborne sensors are a key component of the global atmosphere observing system, playing a crucial role for understanding and monitoring climate change and ozone depletion. The SCanning Imaging Absorption spectroMeter for Atmospheric CHartographY (SCIAMACHY) is one of these sensors. It was launched in March 2002 on board the European ENVIronmental SATellite (ENVISAT). In the nadir (down-looking mode) and limb (the atmosphere is scanned tangentially to the Earth's surface) viewing geometries, the SCIAMACHY instrument measures the sunlight scattered by the Earth's atmosphere or reflected by the surface whereas in the occultation mode, the direct solar or lunar light transmitted through the atmosphere is observed. The measurements are performed in eight spectral channels covering the 240-2400 nm wavelength range. A detailed description of the SCIAMACHY instrument, its observation modes as well as mission objectives and target atmospheric species is given by Bovensmann et al. (1999). Most well-studied and widely used are the observations in the nadir viewing mode, from which total columns of atmospheric species can be retrieved. Regarding the limb measurements used in this study, they provide information on the vertical distributions of atmospheric trace gases and aerosols in the stratosphere. However, due to the complexity of the scattering processes associated with the detection of the solar light in the limb viewing geometry, sophisticated forward modeling and inversion approaches are required to retrieve the atmospheric composition from this kind of measurement. 
Since the launch of ENVISAT in 2002, several studies have demonstrated the reliability of SCIAMACHY limb measurements of trace species involved in ozone depletion like ozone itself (e.g. von Savigny et al., 2005; Brinksma et al., 2006; Butz et al., 2006; Rozanov et al., 2007), nitrogen dioxide (e.g. Bracher et al., 2005; Rozanov et al., 2005a; Butz et al., 2006), and bromine monoxide (e.g. Rozanov et al., 2005a; Sinnhuber et al., 2005; Dorf et al., 2006; Sioris et al., 2006; Sheode et al., 2006). In the case of bromine monoxide (BrO), a limited number of SCIAMACHY profiles were compared to correlative balloon measurements for verification purpose (Rozanov et al., 2005a; Dorf et al., 2006; Sioris et al., 2006). In this paper, we present the results of the first multi-year comparison exercise of $\mathrm{BrO}$ vertical distributions retrieved from SCIAMACHY limb measurements (version 3.2 of the scientific product from the Institute of Environmental Physics (IUP/IFE) at the University of Bremen) and ground-based zenith-sky UV-visible observations. Based on the dependence of the mean scattering height on solar zenith angle (SZA), low vertical resolution stratospheric $\mathrm{BrO}$ profiles can be retrieved from ground-based UV-visible observations at twilight (e.g. Schofield et al., 2004; Hendrick et al., 2007, 2008). Given the fact that ground-based UV-visible spectrometers can be operated year-round at different sites, a great number of large data sets of $\mathrm{BrO}$ profiles could be potentially made available for intercomparison purpose. In the present study, we have used ground-based UV-visible measurements at three stations belonging to the Network for the Detection of Atmospheric Composition Change (NDACC; http://www.ndacc.org): Observatoire de Haute-Provence in Southern France (OHP, 44 $\left.{ }^{\circ} \mathrm{N}, 5.5^{\circ} \mathrm{E}\right)$, Harestua in Southern Norway $\left(60^{\circ} \mathrm{N}, 11^{\circ} \mathrm{E}\right)$, and Lauder in New Zealand $\left(45^{\circ} \mathrm{S}, 170^{\circ} \mathrm{E}\right)$. The period covered by the comparison is September 2002-October 2006 at Harestua, February 2005November 2006 at OHP, and September 2002-October 2005 at Lauder. One should note that our measurements at Reunion Island $\left(21^{\circ} \mathrm{S}, 56^{\circ} \mathrm{E}\right.$; Theys et al., 2007) have been omitted here mainly because the quality of the vertical profile retrievals was found to be not high enough.

The paper is divided into four parts. The SCIAMACHY limb and ground-based UV-visible BrO profile retrievals are described in the first and second parts, respectively. The third part is dedicated to the characterization of the information content in both SCIAMACHY limb and ground-based UV-visible retrievals. Finally, the comparison results are presented in the fourth part, first for both mid-latitude stations (OHP and Lauder) and secondly for the high-latitude Harestua site.

\section{SCIAMACHY limb BrO retrieval}

The vertical distribution of $\mathrm{BrO}$ on a global scale is retrieved at the Institute of Environmental Physics (IUP) of the University of Bremen from the measurements of scattered so- lar radiation performed by the SCIAMACHY instrument in the limb viewing geometry. In the present study, the SCIAMACHY Level 1 data of version 6.03 from the European Space Agency (ESA) have been provided as input to the retrieval algorithm. A wavelength calibration has been applied and corrections for memory effect, leakage current, pixel-topixel gain, etalon, and internal stray light have been taken into account. The polarization correction as well as the absolute radiometric calibration have been skipped.

The profile retrieval is done using the differential two-step inversion approach implemented in the SCIATRAN software package (Rozanov et al., 2005b; see also http://www.iup. uni-bremen.de/sciatran). A short description of the retrieval method is given below, whereas a more detailed description can be found in previous publications (Rozanov et al., 2005a, 2007; von Savigny et al., 2005). In this study, version 3.2 of the retrieval algorithm has been used. This latest retrieval version uses the same inversion algorithm as earlier versions (1.x), described in the above cited papers, differing, however, quite strongly in the retrieval parameter settings. For example, a slightly different spectral range and a higher reference tangent height were used, Levenberg-Marquardt iterative scheme was replaced by more common Newton-type iterations, and the regularization parameters were optimized. Furthermore, additional information on pressure and temperature provided by the European Centre for Medium-Range Weather Forecasts (ECMWF) was used. A detailed list of the retrieval parameter settings for the current and previous versions of the retrieval software can be found at the data archive web page of the IUP Bremen (http://www.iup.physik. uni-bremen.de/ $\sim$ sciaproc/CDI/DOCU/).

The retrieval is performed in the $338.0-356.2 \mathrm{~nm}$ spectral range using the normalized limb spectra, i.e. each limb spectrum measured in the selected range of tangent heights $(\sim 9-31 \mathrm{~km})$ is divided by the limb spectrum at a higher (reference) tangent height (about $35 \mathrm{~km}$ in this study). Using this approach, the solar Fraunhofer structure is easily accounted for and the impact of imperfect instrument calibration is strongly reduced. To account for broadband spectral features due to unknown atmospheric parameters (e.g. albedo and aerosols), polynomials are subtracted from the normalized limb spectra at all tangent heights of interest. This procedure is similar to that of the standard DOAS (Differential Optical Absorption Spectroscopy) approach (Platt and Stutz, 2008). At the first retrieval step, also referenced as the preprocessing step, a spectral fit is performed for each limb spectrum independently to find the scaling factors for the spectral corrections (in this study: tilt, ring, $1 / I_{0}$, eta (polarization response); see e.g. Sioris et al. (2006) and Kühl et al. (2008) for details) as well as to account for a possible wavelength misalignment. Thereafter, all fitted corrections are applied and the main retrieval step is initiated employing the global fit method (i.e., the spectra obtained at all tangent heights are fitted simultaneously). The measurement vector comprises all spectral points in the selected 
spectral range obtained at all tangent heights of interest and the Optimal Estimation Method (Rodgers, 2000) is applied to obtain the vertical profiles of $\mathrm{BrO}$. However, an additional smoothing constraint was introduced whereas the statistical constraint is relaxed by setting the a priori standard deviations to $25 \mathrm{pptv}$. If the corresponding value in concentration is larger than $4 \times 10^{7} \mathrm{molec} / \mathrm{cm}^{3}$, the standard deviation is set to $4 \times 10^{7} \mathrm{molec} / \mathrm{cm}^{3}$. A priori standard deviations larger than the $\mathrm{BrO}$ natural variability ensure good retrieval results even if the a priori profiles are unrealistic or if atmospheric $\mathrm{BrO}$ concentrations are abnormally large (e.g., due to volcanic eruption). The noise covariance is determined by the fit residuals at the preprocessing step. The non-linearity of the problem is accounted for using the Newton-type iterative approach. The simulated spectra and appropriate weighting functions are calculated using the SCIATRAN radiative transfer model which includes a fully spherical treatment of the singly scattered radiation and an approximation for the multiple scattering. The weighting functions are calculated in the single scattering approximation.

In the fit procedure, the spectral signatures of $\mathrm{BrO}, \mathrm{O}_{3}$, $\mathrm{NO}_{2}$, and $\mathrm{O}_{4}$ have been taken into account. The forward model was initialized using the global pressure and temperature information provided by the ECMWF and a climatological database containing monthly averaged vertical distributions of ozone and $\mathrm{NO}_{2}$ (McLinden et al., 2002) for 10 degree latitude bands as well as of $\mathrm{BrO}$ for 5 degree latitude bands. The $\mathrm{BrO}$ a priori profile climatology is calculated from an estimate of $\mathrm{Br}_{\mathrm{y}}$ based on MIPAS measurements of CFC-11 for 2003 using the empirical relation between CFC11 and $\mathrm{Br}_{\mathrm{y}}$ of Wamsley et al. (1998) with updated surface mixing ratios for the individual source gases (Sinnhuber et al., 2005). The $\mathrm{BrO}$ profile climatology is then calculated from these $\mathrm{Br}_{\mathrm{y}}$ profiles assuming a $\mathrm{BrO} / \mathrm{Br}_{\mathrm{y}}$ ratio of $50 \%$, which is a reasonable approximation for daytime conditions. It is worth noting that the dependence on the a priori information in the sensitivity region (see Sect. 4) is insignificant (Rozanov et al., 2005a). The vertical distribution of $\mathrm{O}_{4}$ was calculated using the corresponding vertical profile of the air density. Furthermore, the temperature dependent absorption cross sections of $\mathrm{BrO}$ obtained by the time-windowing Fourier transform spectroscopy (TW-FTS) technique (Fleischmann et al., 2004), of $\mathrm{O}_{3}$ and $\mathrm{NO}_{2}$ measured by the SCIAMACHY PFM Satellite Spectrometer (Bogumil et al., 2003), as well as the $\mathrm{O}_{4}$ cross sections from Greenblatt et al. (1990) have been used. Regarding the $\mathrm{BrO}$ cross-sections choice, Fleischmann et al. (2004) allows to take into account the temperature dependence more properly since cross sections are available at 5 temperatures (instead of 2 in Wilmouth et al., 1999). Sensitivity tests have also shown that both cross sections sets give similar DOAS fit residuals. A constant surface albedo of 0.3 has been assumed and clouds were completely neglected (a cloud free atmosphere is assumed for all retrievals, independently of the reality). The retrieval is found to be almost insensitive to the surface albedo and the lower clouds because the measured limb signal contains not much information originating from the lower atmospheric layers due to a relatively strong extinction of the solar light. This is confirmed by the averaging kernels showing that for tangent heights above $15 \mathrm{~km}$ the bulk of information originates from the upper layers (see Sect. 4). Preliminary investigations have also shown that the error due to a wrong surface albedo or inappropriate treatment of the lower clouds decrease rapidly with the increasing altitude reaching only several percents around $15 \mathrm{~km}$, which is far below the retrieval error in this altitude region. The measurements where a high cloud appears in the field of view of the instrument can be affected more strongly. However, at the locations considered in this study, the probability of high clouds (above about $14 \mathrm{~km}$ ) is quite small. One should also note that sensitivity tests have shown that our comparison results do not change noticeably if cloudy scenes are rejected. Regarding the aerosols, a background loading according to the LOWTRAN parameterization (Kneizys et al., 1986) has been assumed. For a relatively clean stratosphere as it occurs in the recent years, the influence of the stratospheric aerosols on the retrieved vertical profiles of $\mathrm{BrO}$ is estimated to be commonly below $10 \%$.

With respect to the previously reported version 1.1 data set (Sinnhuber et al., 2005), the spectral information provided as input and the retrieval settings have undergone substantial changes as already mentioned above, making the version 3.2 profiles completely different from the previous results. Among the major differences in the data preparation and the retrieval, one should mention the use of the newest calibrated Level 1 data set (calibration settings are listed above) instead of uncalibrated Level 0 data which includes a proper setting of the tangent height information. Being currently known to better than $200 \mathrm{~m}$, the pointing offset was found to vary between 0 and $3 \mathrm{~km}$ for earlier data sets. In version 1.1 of the retrieval algorithm, this uncertainty was approximated by a constant downward shift of $1.5 \mathrm{~km}$ which resulted sometimes in vertically shifted and oscillating $\mathrm{BrO}$ profiles. Furthermore, the introduction of a smoothing constrain and use of a constant (instead of changing with iterations) a priori $\mathrm{BrO}$ profile helped to get rid of oscillations in the retrieved profiles. Thus, although the overall form of the retrieved profiles of versions 1.1. and 3.2 is similar, relative differences of $100 \%$ or even larger can be observed because of the vertical shift and oscillations of the previous retrieval results. An example comparison of versions 1.1 and $3.2 \mathrm{BrO}$ vertical profiles for 5 May 2003 close to Harestua is shown in Fig. 1.

\section{Ground-based UV-visible BrO retrieval}

Ground-based zenith-sky UV-visible observations of $\mathrm{BrO}$ have been continuously performed at Harestua, OHP, and Lauder since 1998, 2005, and 1995, respectively. A description of the instrumental set-up can be found in Hendrick et 


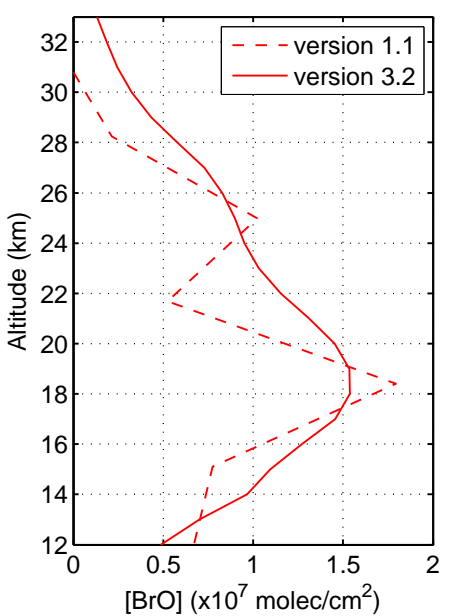

Fig. 1. Comparison between versions 1.1 and 3.2 of SCIAMACHY limb BrO profiles for 5 May 2003 close to Harestua (latitude and longitude at the tangent point: $62.3^{\circ} \mathrm{N}$ and $13.9^{\circ} \mathrm{E}$, respectively). The SZA at tangent point is about $42^{\circ}$ and the orbit and state numbers are 6531 and 27 (NRT Level 0 file $n^{\circ} 442$ ) for version 1.1 profile and 6532 and 11 for version 3.2 profile.

al. (2007) and Theys et al. (2007) for Harestua and OHP and in Schofield et al. (2004) for Lauder. Measured zenith radiance spectra are analysed using the DOAS technique (Platt and Stutz, 2008). Similar DOAS settings have been applied to the three data sets. In brief, the spectral signatures of $\mathrm{NO}_{2}$, $\mathrm{O}_{3}, \mathrm{O}_{4}, \mathrm{OClO}$ (OHP and Lauder do not fit OClO because there is no $\mathrm{OClO}$ at mid-latitude), and the Ring effect have been taken into account. The retrieval of $\mathrm{BrO}$ at the three stations relies on the same $\mathrm{BrO}$ cross sections (Wilmouth et al., 1999), as recommended by Aliwell et al. (2002). Sensitivity tests have shown that both Wilmouth et al. (1999) and Fleischmann et al. (2004) BrO cross sections sets give similar DOAS fit residuals, as for SCIAMACHY limb retrieval. The fitting windows are $345-359 \mathrm{~nm}$ for Harestua and OHP and $342-357 \mathrm{~nm}$ for Lauder. More details on the DOAS settings can be found in Theys et al. (2007) and Schofield et al. (2004).

Stratospheric $\mathrm{BrO}$ profiles have been retrieved by applying a profiling technique to the $\mathrm{BrO}$ differential slant column densities (DSCDs), which are the direct product of the DOAS analysis. The profiling algorithm is based on the Optimal Estimation Method (Rodgers, 2000) and is described in Hendrick et al. (2007). It is important to note that the forward model includes a stacked box photochemical model in order to reproduce the rapid variation of $\mathrm{BrO}$ at twilight (see e.g. Fish et al., 1995, for a typical example of the stratospheric $\mathrm{BrO}$ diurnal variation at mid-latitude). Therefore, the retrieved profiles can be easily photochemically corrected to correspond to the SZA of the SCIAMACHY observations (SZA at tangent point). One should note that, because the stratospheric $\mathrm{BrO}$ concentration is essentially controlled by $\mathrm{NO}_{2}$ through the termolecular reaction $\mathrm{BrO}+\mathrm{NO}_{2}+\mathrm{M} \rightarrow \mathrm{BrONO}_{2}$, the photochemical simulations have been constrained by the $\mathrm{NO}_{2}$ profiles retrieved from simultaneous zenith-sky observations in the visible region (Hendrick et al., 2004). BrO DSCDs are evaluated using daily reference spectra, the effective residual amount of $\mathrm{BrO}$ in the reference spectra being directly fitted by the profiling algorithm. The term "effective" is used because the fitted quantity also includes the tropospheric contribution to the total BrO column. This makes the retrieval only sensitive to the stratosphere (Hendrick et al., 2004, 2007, 2008). At Harestua, retrievals are not performed between end of October and mid-February. During this period, the quality of the retrieval is lower, mainly because the SZA range corresponding to the BrO DSCDs is smaller (SZA at local noon can reach $84^{\circ}$ at $60^{\circ} \mathrm{N}$ ) and therefore the information content is somewhat lower than it is for the rest of the year (Hendrick et al., 2007). It has been also shown in Hendrick et al. (2007) that the impact of the uncertainties on surface albedo and stratospheric aerosols on the retrieved profiles and corresponding columns is less than $2 \%$ and $4 \%$, respectively.

\section{Information content from SCIAMACHY limb and ground-based UV-visible retrievals}

The averaging kernels matrix $\mathbf{A}$ is a key parameter in the characterization of the information content of a retrieval. The averaging kernels express the sensitivity of the retrieved profile to the true atmospheric profile (Rodgers, 2000). The FWHM (full width at half maximum) of an averaging kernel at a given altitude provides a rough estimate of the vertical resolution at this altitude and the trace of $\mathbf{A}$, which is the number of degrees of freedom for signal, gives an estimate of the number of independent pieces of information contained in the measurements. The measurement response function can also be used to characterize a retrieval. This function is given by the area of the averaging kernels and describes how much information comes from the measurements. Values close to one indicate that most of the information comes from the measurements whereas values below 0.5 indicate a significant influence of the a priori information on the retrieved profile. Typical examples of SCIAMACHY limb and ground-based UV-visible BrO averaging kernels and measurement response functions for morning and evening retrievals are shown in Figs. 2 and 3, respectively. They correspond to the Harestua 16 April 2003 morning and 26 June 2005 evening retrievals. The evening SCIAMACHY retrievals originate from the back side of the ENVISAT orbits in late spring/summer at high latitudes and therefore are only available at Harestua.

From the examination of the averaging kernels and measurement response functions, it is found that in case of SCIAMACHY limb retrievals, the altitude region with high 

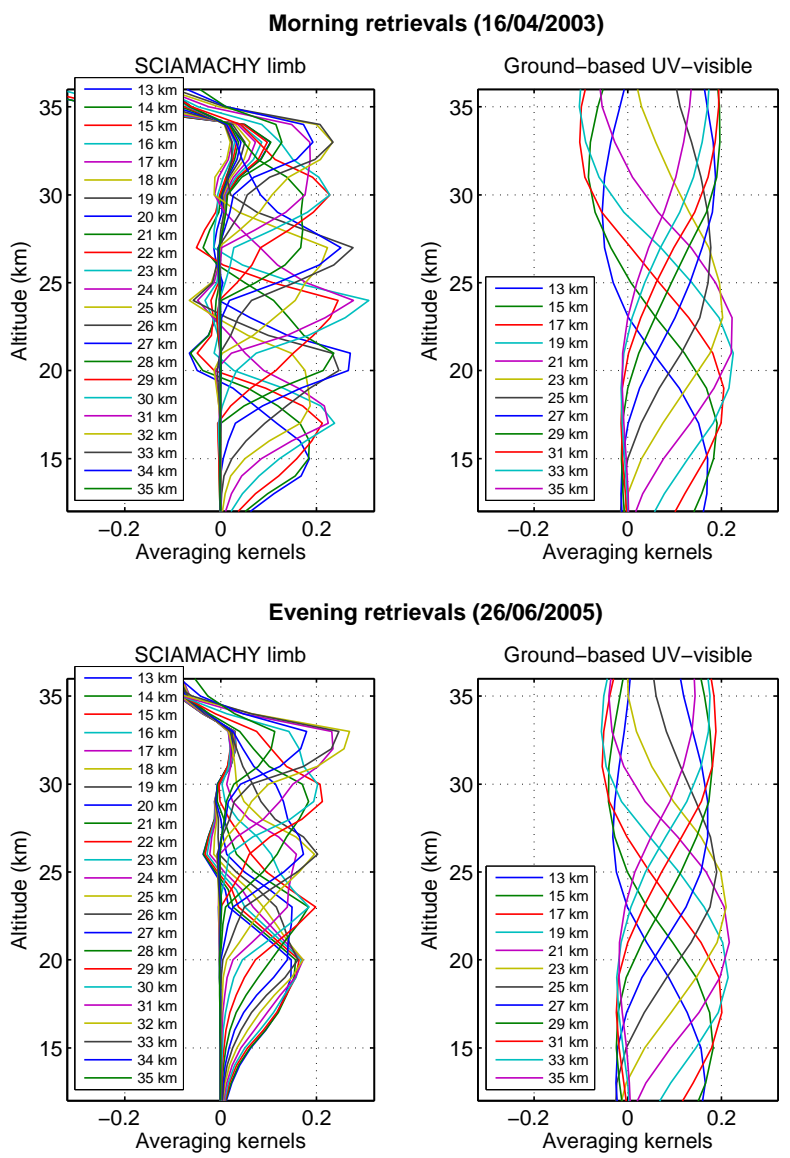

Fig. 2. Typical examples of averaging kernels for morning (upper plots) and evening (lower plots) SCIAMACHY limb and groundbased UV-visible BrO retrievals. They correspond to the Harestua 16 April 2003 morning and 26 June 2005 evening retrievals.
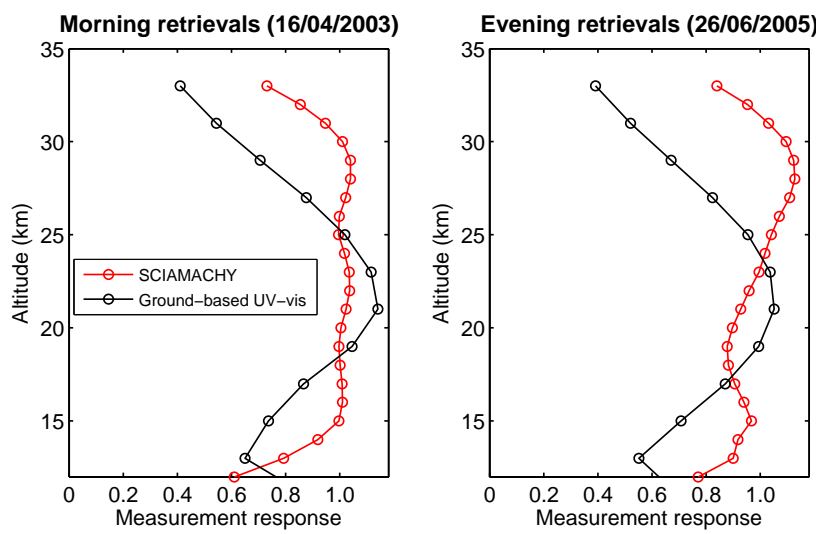

Fig. 3. Typical examples of measurement response functions for morning (left plot) and evening (right plot) SCIAMACHY limb and ground-based UV-visible BrO retrievals. They correspond to the Harestua 16 April 2003 morning and 26 June 2005 evening retrievals. sensitivity to the $\mathrm{BrO}$ vertical distribution is $15-33 \mathrm{~km}$ and $18-33 \mathrm{~km}$ for morning and evening conditions, respectively. In both cases, the vertical resolution is between 3 and $5 \mathrm{~km}$. The smaller sensitivity to $\mathrm{BrO}$ obtained in the lower altitude levels $(15-18 \mathrm{~km})$ for evening retrievals is due to the fact that at large SZA, less light penetrates to the lower layers of the atmosphere leading to a worse signal to noise ratio in the limb spectra measured at lower tangent heights.

In case of ground-based UV-visible retrievals, measurement response functions are similar for both morning and evening conditions but morning averaging kernels peak too high by about $2 \mathrm{~km}$, in contrast to evening conditions where the averaging kernels peak at their nominal altitudes. Looking at the $\mathrm{BrO}$ weighting functions used to calculate the averaging kernels, it appears that the morning weighting functions at SZA larger than $90^{\circ}$ are shifted higher by about $2 \mathrm{~km}$ with respect to the corresponding evening weighting functions. Since the same pressure, temperature, and ozone profiles are used to calculate both morning and evening weighting functions, this feature is more likely due differences between sunrise and sunset $\mathrm{BrO}$ concentration profiles: the release of $\mathrm{BrO}$ from its nighttime reservoir $\mathrm{BrONO}_{2}$ at sunrise is more rapid than the formation of $\mathrm{BrONO}_{2}$ at sunset, resulting in different $\mathrm{BrO}$ profile shapes at sunrise and sunset. Based on the measurements response functions and averaging kernels, the altitude region with high sensitivity to $\mathrm{BrO}$ is found to be $13-27 \mathrm{~km}$ for ground-based retrievals. Therefore, $15-27 \mathrm{~km}$ and $18-27 \mathrm{~km}$ are the common altitude ranges chosen for morning and evening comparisons, respectively. Figure 2 also shows that the vertical resolution is 10 $12 \mathrm{~km}$ at best for ground-based UV-visible retrievals. Averaging kernels similar to those corresponding to the Harestua 16 April 2003 morning retrieval are obtained at OHP and Lauder.

Due to the difference in vertical resolution, the SCIAMACHY profiles should be degraded to the resolution of the ground-based profiles in order to allow direct comparison (Hendrick et al., 2004, 2007). This is done by convolving the SCIAMACHY profiles with the coincident ground-based UV-visible averaging kernels using the following expression (Connor et al., 1994):

$\mathbf{x}_{\text {sscia }}=\mathbf{x}_{a}+\mathbf{A}\left(\mathbf{x}_{\text {scia }}-\mathbf{x}_{a}\right)$

where $\mathbf{A}$ is the ground-based averaging kernels matrix, $\mathbf{x}_{a}$ is the a priori profile used in the ground-based retrieval, $\mathbf{x}_{\text {scia }}$ is the SCIAMACHY profile, and $\mathbf{x}_{\text {sscia }}$ is the smoothed or convolved SCIAMACHY profile which represents what the retrieval should produce assuming that $\mathbf{x}_{\text {scia }}$ is the true profile and that the only source of error is the smoothing error.

In this method, the vertical resolution of SCIAMACHY is neglected when convolving the SCIAMACHY profiles with the ground-based averaging kernels. This is a reasonable assumption given the large difference in vertical resolution between SCIAMACHY and ground-based UV-visible profiles (see above). According to Eq. (1), SCIAMACHY 

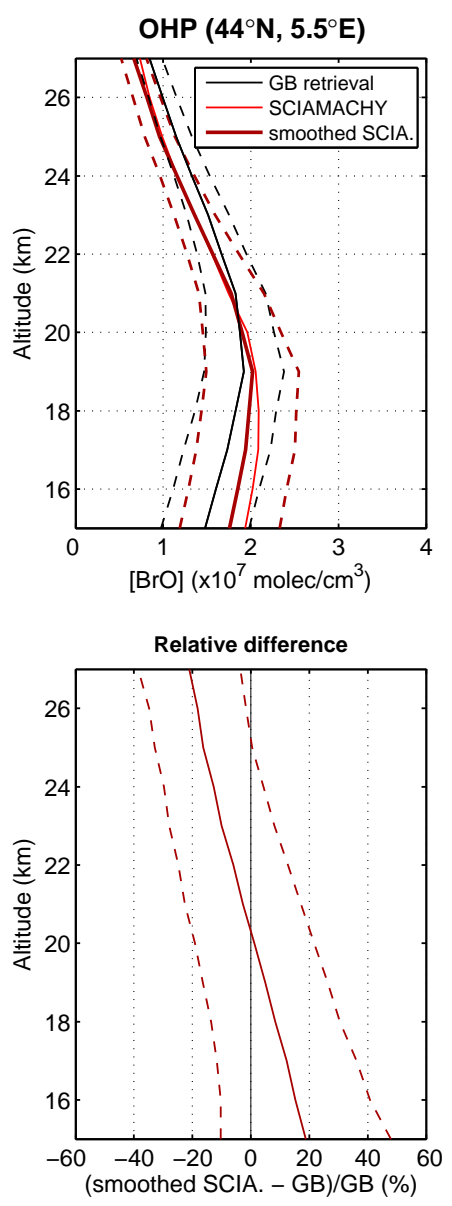

Fig. 4. Comparison between mean SCIAMACHY limb (thin red and thick dark red solid lines) and ground-based UV-visible $\mathrm{BrO}$ profiles (solid black line) at $\mathrm{OHP}\left(44^{\circ} \mathrm{N}, 5.5^{\circ} \mathrm{E}\right)$ for morning conditions for the 2005-2006 period (265 coincidences). The mean relative differences appear in the lower plot. They have been plotted for the smoothed SCIAMACHY profile. In both plots, the dashed lines represent the one-sigma standard deviation. The standard deviation of the unsmoothed SCIAMACHY profile is similar to the one calculated for the smoothed profile.

profiles have to be extended to the same altitude grid as the ground-based UV-visible averaging kernels. In the present study, the SCIAMACHY profiles have been completed below and above the covered altitude range by the groundbased a priori profiles scaled by the ratios between the retrieved SCIAMACHY and ground-based a priori profiles at the lower and upper altitude limits of the SCIAMACHY profiles, respectively. This scaling prevents from the occurence of discontinuities at the lower and upper altitude limits of the SCIAMACHY profiles (Hendrick et al., 2004). However, it should be noted that this smoothing method introduces an additional uncertainty above $\sim 25 \mathrm{~km}$ and especially below $\sim 18 \mathrm{~km}$ which is related to the SCIAMACHY profiles extrapolation procedure.
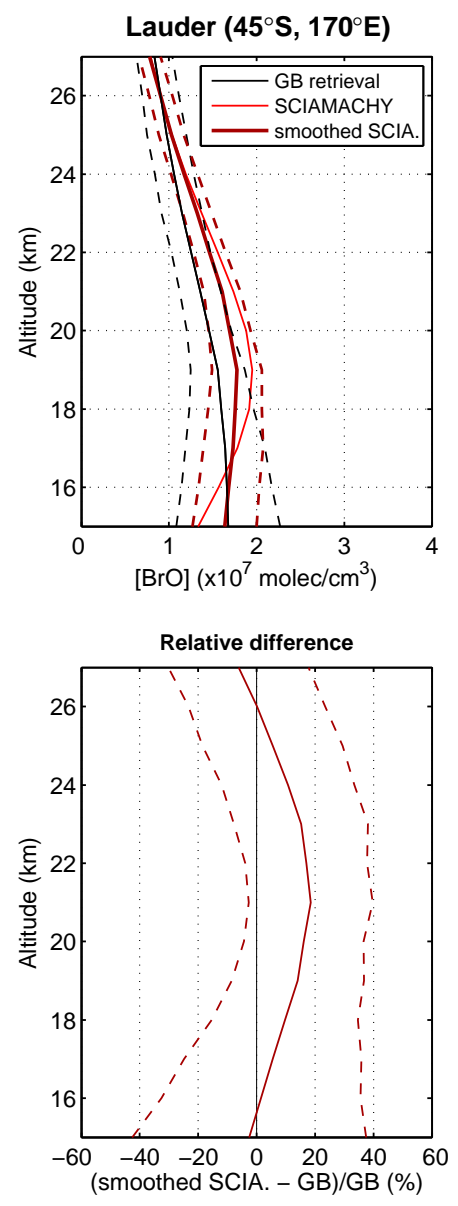

Fig. 5. Comparison between mean SCIAMACHY limb (thin red and thick dark red solid lines) and ground-based UV-visible $\mathrm{BrO}$ profiles (solid black line) at Lauder $\left(45^{\circ} \mathrm{S}, 170^{\circ} \mathrm{E}\right)$ for morning conditions for the 2002-2005 period (517 coincidences). The mean relative differences appear in the lower plot. They have been plotted for the smoothed SCIAMACHY profile. In both plots, the dashed lines represent the one-sigma standard deviation. The standard deviation of the unsmoothed SCIAMACHY profile is similar to the one calculated for the smoothed profile.

The number of independent pieces of information in both SCIAMACHY and ground-based UV-visible measurements has been estimated. The values of the trace of $\mathbf{A}$ are about 4.5 and 3.5 for SCIAMACHY morning and evening retrievals, respectively, while it reaches 2.5 for ground-based UV-visible retrievals (these values are given for the whole stratosphere).

\section{Comparison results}

In this section, stratospheric $\mathrm{BrO}$ profiles and corresponding partial columns retrieved from ground-based UV-visible measurements at Harestua, OHP, and Lauder are compared to coincident SCIAMACHY limb data. One should note that in 
all comparison plots, ground-based data are arbitrarily taken as reference for the calculation of relative differences. As discussed in Sect. 4, comparison results are shown for the $15-27 \mathrm{~km}$ altitude range, except for Harestua evening coincidences where the $18-27 \mathrm{~km}$ altitude range is used. $\mathrm{BrO}$ partial columns are calculated by integrating the vertical profiles in these altitude ranges. For the selection of the SCIAMACHY profiles, the following spatial coincidence criterion is chosen: the average latitude and longitude at tangent point should fall within latitude of the stations $\pm 5^{\circ}$ and longitude of the stations $\pm 10^{\circ}$. This corresponds to a maximum distance between SCIAMACHY and ground-based UV-visible observations of about $750 \mathrm{~km}$. Sensitivity tests have shown that tighten up the spatial coincidence criterion to a maximum distance of $250 \mathrm{~km}$ does not change significantly the comparison results. Concerning the temporal criterion, SCIAMACHY profiles are compared to ground-based profiles retrieved from the same morning (or evening) slant column densities and the photochemical model PSCBOX included in the profiling algorithm (see Sect. 3) is used to convert the ground-based profiles to values appropriate to the SZA at the tangent point area of the coincident SCIAMACHY limb observations. This ensures photochemical matching, within the accuracy of the photochemical model, for both SCIAMACHY and ground-based profiles. This is an important criterion when comparing measurements of species having a strong diurnal variation such as BrO. However, because of differences in the local time of the observations (typically $3 \mathrm{~h}$ in winter and up to $6 \mathrm{~h}$ (OHP and Lauder) and $8 \mathrm{~h}$ (Harestua) around the summer solstice), an uncertainty due to possible dynamical fluctuations still remains. When applying these criteria, we found 265 morning coincidences events at OHP for the February 2005-November 2006 period. At Harestua, 561 coincidences have been selected for September 2002-October 2006 period, including 512 morning coincidences and 49 evening coincidences. It should be noted that in case of evening coincidences, SCIAMACHY and ground-based measurements occur at almost the same local time, i.e. around $85^{\circ}$ SZA. At Lauder, we found 517 morning coincidences for the September 2002-October 2005 period.

\subsection{OHP and Lauder}

Figures 4 and 5 show the comparison between mean SCIAMACHY and ground-based UV-visible BrO profiles at OHP and Lauder, respectively. A reasonably good agreement is found in the whole $15-27 \mathrm{~km}$ altitude range with relative difference smaller than $21 \%$. At OHP, the ground-based profile is lower than SCIAMACHY between 15 and $20 \mathrm{~km}$ while the opposite is found above $20 \mathrm{~km}$. At Lauder, the groundbased profile is systematically lower than SCIAMACHY in the $15.5-26.5 \mathrm{~km}$ altitude range with a maximum relative difference of $+19 \%$ around $21 \mathrm{~km}$. In the $18-27 \mathrm{~km}$ altitude range, the ground-based UV-visible retrieval gives sig- nificantly lower $\mathrm{BrO}$ concentration values at Lauder than at OHP, while the corresponding SCIAMACHY profiles are very close. This could be related to the use of not strictly identical DOAS settings for both stations, which can lead to differences in the DSCDs and their corresponding errors. Below $18 \mathrm{~km}$, we see from Figs. 4 and 5 that the unsmoothed SCIAMACHY profile shows significantly lower $\mathrm{BrO}$ concentration values at Lauder than at OHP. Because of the 10$12 \mathrm{~km}$ vertical resolution of the ground-based profiles, the agreement with the smoothed SCIAMACHY profiles in the lower layers $(15-20 \mathrm{~km})$ could be influenced by the smoothing method used, in particular by the way the SCIAMACHY profiles are extended to the ground (see Sect. 4).

Comparison results for the $15-27 \mathrm{~km} \mathrm{BrO}$ partial columns at OHP and Lauder are depicted in Figs. 6 and 7, respectively. At OHP, the agreement between SCIAMACHY and ground-based columns is very good with SCIAMACHY being higher than the ground-based observations by $1 \pm 18 \%$ on average and SCIAMACHY data are most of the time within the error bars associated to the ground-based columns (corresponding to the total error (systematic + random errors) calculated as in Hendrick et al., 2007). At Lauder, a larger discrepancy is obtained, with SCIAMACHY being higher than the ground-based observations by $11 \pm 16 \%$ on average. One should note that a negative bias of about $-10 \%$ is expected in the comparison results if the same Wilmouth et al. (1999) $\mathrm{BrO}$ cross sections had been used in both SCIAMACHY and ground-based UV-visible retrievals (see Sect. 5.2). The seasonality of $\mathrm{BrO}$, directly related to the $\mathrm{NO}_{2}$ seasonal cycle, is also consistently captured at both stations by both SCIAMACHY and ground-based UV-visible retrievals. In both SCIAMACHY and ground-based UV-visible data sets, the $\mathrm{BrO}$ seasonality is less marked at Lauder than at OHP, with larger $\mathrm{BrO}$ column values in winter at OHP than at Lauder. Since the main driver for the $\mathrm{BrO}$ seasonality is the $\mathrm{NO}_{2}$ seasonal cycle, we have examined the $\mathrm{NO}_{2} \quad 15-27 \mathrm{~km}$ partial columns seasonal cycle at both stations derived from SCIAMACHY limb profiles (version 3.1 of the IUP Bremen scientific product; see e.g. Bracher et al., 2005, and Rozanov et al., 2005a). Figure 8 shows that in winter, $\mathrm{NO}_{2}$ partial columns are significantly lower at OHP than at Lauder (by about $30 \%$ in average). Less $\mathrm{NO}_{2}$ at OHP means less $\mathrm{BrONO}_{2}$ and therefore more $\mathrm{HOBr}$ as bromine reservoir. Since $\mathrm{HOBr}$ is photolyzed more rapidly than $\mathrm{BrONO}_{2}$, this can at least partly explain the larger $\mathrm{BrO}$ column values in winter at OHP and therefore the more marked stratospheric $\mathrm{BrO}$ seasonality at this station. Figures 6 and 7 also show that the relative difference between SCIAMACHY and groundbased UV-visible $\mathrm{BrO}$ partial columns has a marked seasonal dependence, with a tendency to have more negative relative difference values in summer than during the rest of the year. This seasonality is most probably related to the difference in the local time of both SCIAMACHY and ground-based observations (performed around 10h local time and at twilight (80-93 $\left.{ }^{\circ} \mathrm{SZA}\right)$, respectively). At OHP and Lauder, this 

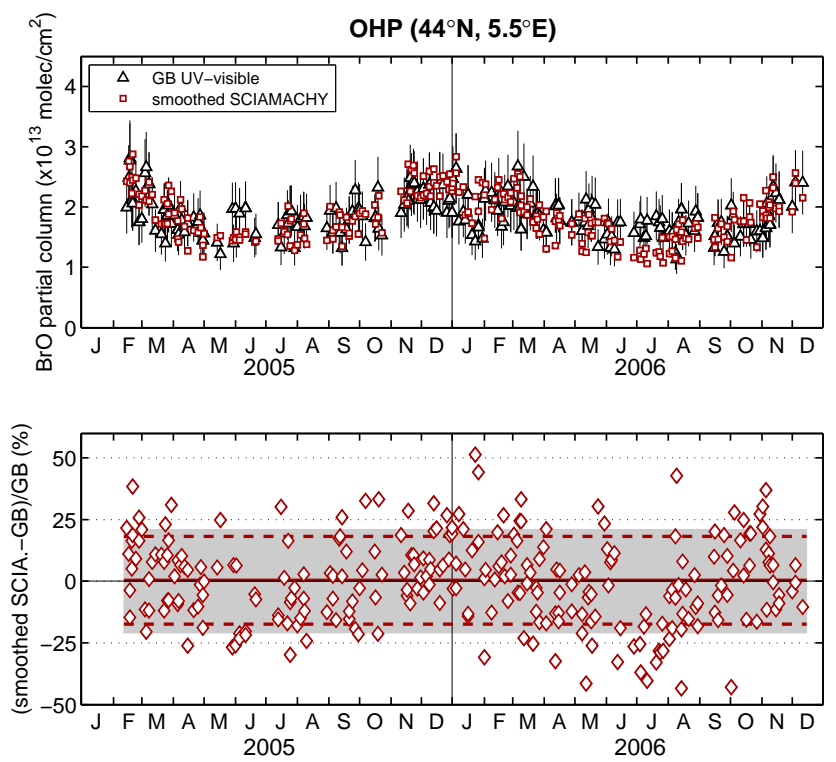

Fig. 6. Comparison of the $15-27 \mathrm{~km}$ BrO partial columns calculated from the smoothed SCIAMACHY limb and ground-based $\mathrm{UV}$-visible profiles at $\mathrm{OHP}\left(44^{\circ} \mathrm{N}, 5.5^{\circ} \mathrm{E}\right)$ for the 2005-2006 period (morning coincidences). The relative differences appear on the lower plot. The error bars on the ground-based data correspond to the total error (systematic error + total retrieval error), estimated as in Hendrick et al. (2007). The solid and dashed red lines in the lower plot correspond to the mean relative difference and its onesigma standard deviation, respectively. The grey-shaded area indicates the mean uncertainty region for the ground-based UV-visible partial columns.

difference is about $3 \mathrm{~h}$ in winter and can reach up to $6 \mathrm{~h}$ at the summer solstice. Therefore, a larger impact of the photochemical correction applied to the ground-based profiles is expected in summer. This photochemical correction depends mainly on the accuracy of the $\mathrm{NO}_{2}$ profiles used to initialize the stacked box photochemical model and on the uncertainties of the reaction rates. As mentioned in Sect. 3, stratospheric $\mathrm{NO}_{2}$ profiles retrieved from simultaneous zenith-sky observations in the visible region have been used. The accuracy of the columns corresponding to these profiles is about $10 \%$ (Hendrick et al., 2004). Since $\mathrm{NO}_{2}$ columns display a strong seasonality with a maximum in summer and a minimum in winter, one can expect in late spring/summer a larger impact of this parameter on the photochemically corrected $\mathrm{BrO}$ profiles and corresponding columns. This is confirmed by sensitivity tests performed for the three stations using the stacked box photochemical model PSCBOX. We found that an uncertainty of $10 \%$ in the stratospheric $\mathrm{NO}_{2}$ columns has an impact of $2 \%$ on the $15-27 \mathrm{~km} \mathrm{BrO}$ partial column in winter, while this impact reaches $5 \%$ of the $\mathrm{BrO}$ partial column values in summer. Model calculations have also shown that the impact of the rate uncertainty of the termolecular reaction $\mathrm{BrO}+\mathrm{NO}_{2}+\mathrm{M}$ displays a seasonality: an impact of
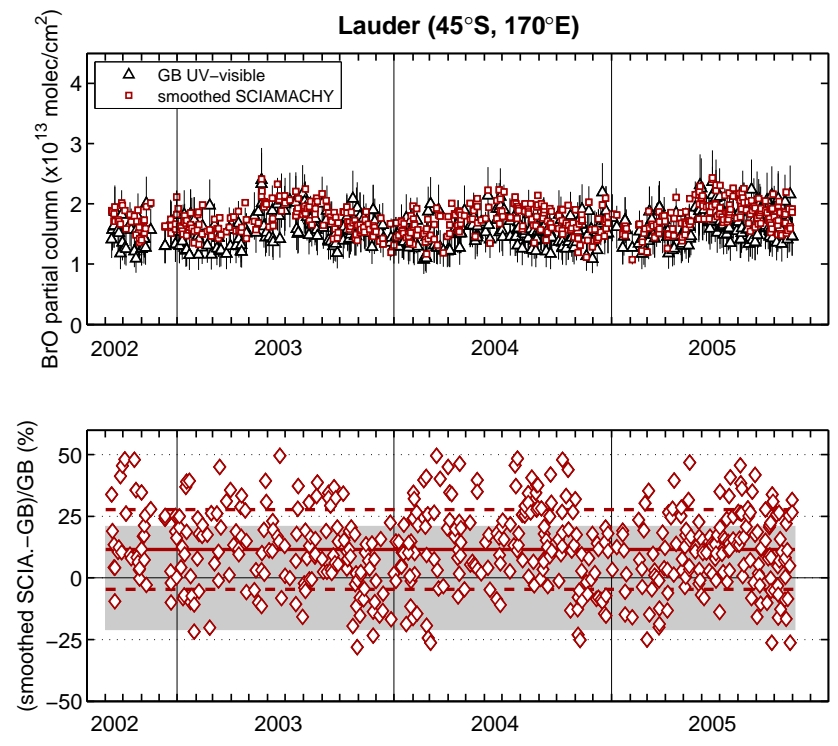

Fig. 7. Comparison of the $15-27 \mathrm{~km}$ BrO partial columns calculated from the smoothed SCIAMACHY limb and ground-based $\mathrm{UV}$-visible profiles at Lauder $\left(45^{\circ} \mathrm{S}, 170^{\circ} \mathrm{E}\right)$ for the $2002-2005$ period (morning coincidences). The relative differences appear on the lower plot. The error bars on the ground-based data correspond to the total error (systematic error + total retrieval error), estimated as in Hendrick et al. (2007). The solid and dashed red lines in the lower plot correspond to the mean relative difference and its onesigma standard deviation, respectively. The grey-shaded area indicates the mean uncertainty region for the ground-based UV-visible partial columns.

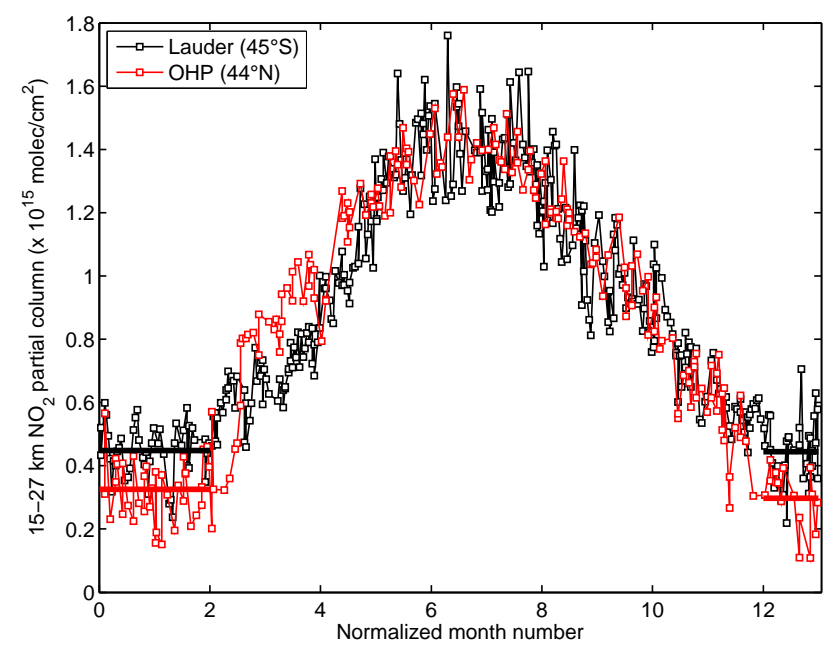

Fig. 8. Typical $15-27 \mathrm{~km} \mathrm{NO}_{2}$ partial column seasonal cycle at Lauder $\left(45^{\circ} \mathrm{S}, 170^{\circ} \mathrm{E}\right)$ and $\mathrm{OHP}\left(44^{\circ} \mathrm{N}, 5.5^{\circ} \mathrm{E}\right)$ derived from SCIAMACHY limb profiles. At Lauder, month 0 corresponds to June 2003 and month 12 to June 2004. At OHP, month 0 corresponds to December 2005 and month 12 to December 2006. Thick solid lines correspond to mean partial columns for the months 0-2 and month 12 periods (red OHP; black: Lauder). 

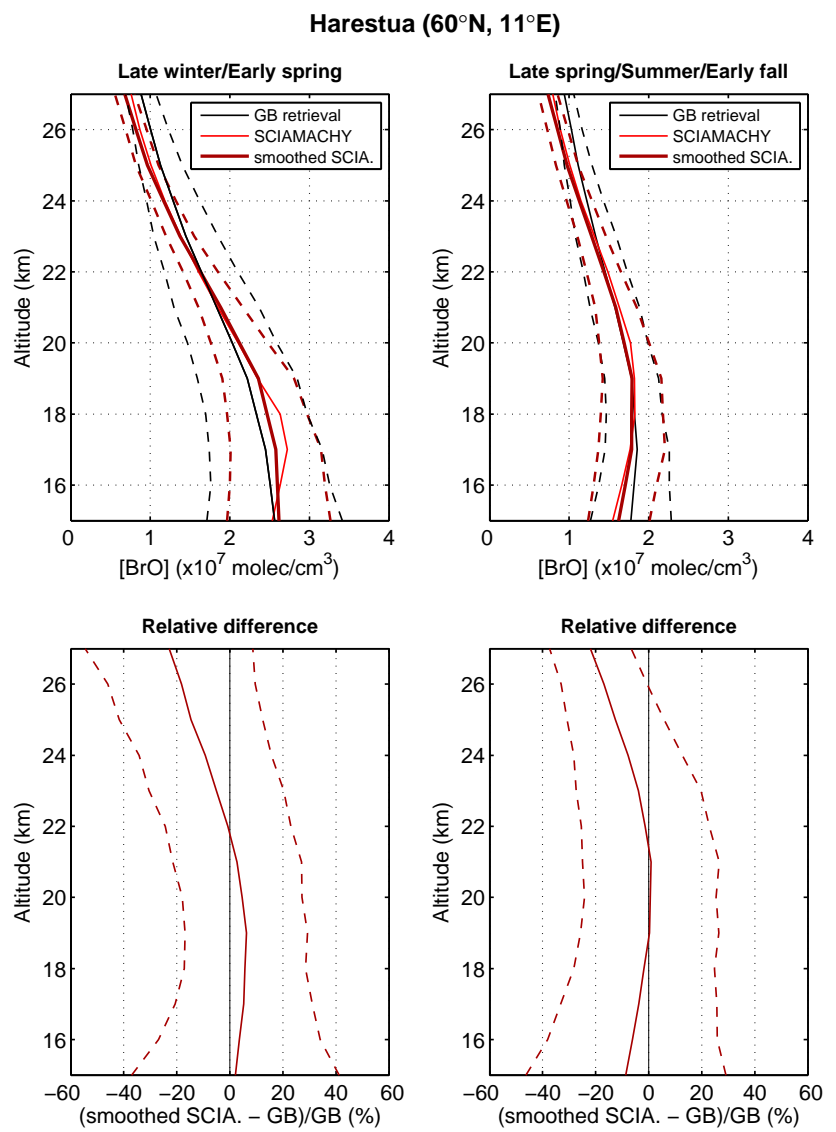

Fig. 9. Comparison between mean SCIAMACHY limb (thin red and thick dark red solid lines) and ground-based UV-visible $\mathrm{BrO}$ profiles (solid black line) at Harestua $\left(60^{\circ} \mathrm{N}, 11^{\circ} \mathrm{E}\right)$ for the 2002-2006 period (morning coincidences). Profiles have been plotted separately for late winter/early spring (left plot) and late spring/summer/early fall (right plot) conditions. The number of coincident events is 154 and 358, respectively. The mean relative differences appear in the lower plots. They have been plotted for the smoothed SCIAMACHY profiles. In the four plots, the dashed lines represent the one-sigma standard deviation. The standard deviation of the unsmoothed SCIAMACHY profiles is similar to the one calculated for the smoothed profiles.

$4 \%$ or less on the retrieved $\mathrm{BrO}$ partial columns is found in winter at both stations, while this impact is around $10 \%$ in summer. The seasonality in the agreement between SCIAMACHY and ground-based UV-visible BrO partial columns could also be partly related to the SCIAMACHY observation geometry, namely, due to the variation of the SZA at tangent point throughout the year (significantly smaller SZA values in summer than in winter/early spring). Smaller SZA values in summer mean more light due to shorter light paths from the Sun to the scattering point. Therefore, for SCIAMACHY measurements in summer, a better signal to noise ratio is measured and, thus, a better sensitivity to the lower layers as compared to the winter measurements performed at larger SZA.
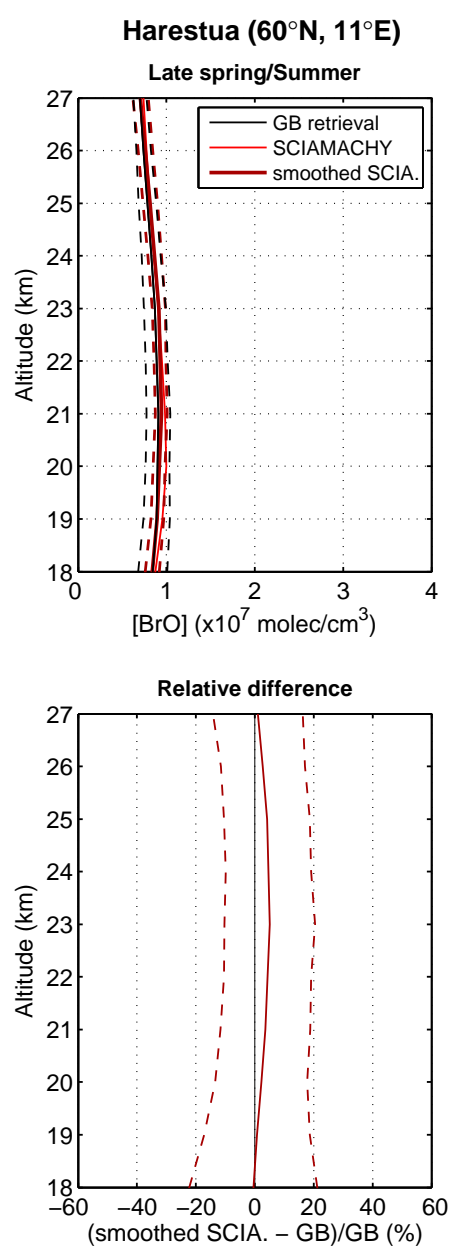

Fig. 10. Comparison between mean SCIAMACHY limb (thin red and thick dark red solid lines) and ground-based UV-visible $\mathrm{BrO}$ profiles (solid black line) at Harestua $\left(60^{\circ} \mathrm{N}, 11^{\circ} \mathrm{E}\right)$ for evening conditions for the 2002-2006 period (49 coincidences). The mean relative differences appear in the lower plot. They have been plotted for the smoothed SCIAMACHY profile. In both plots, the dashed lines represent the one-sigma standard deviation. The standard deviation of the unsmoothed SCIAMACHY profile is similar to the one calculated for the smoothed profile.

\subsection{Harestua}

Morning $\mathrm{BrO}$ profiles have been averaged separately for late winter/early spring and late spring/summer/early fall periods because in late winter/early spring, large stratospheric $\mathrm{BrO}$ enhancement events associated to bromine activation regularly occur over Harestua when the polar vortex is present. The number of coincidences for both periods is 154 and 358, respectively. Figure 9 shows the comparison results of mean ground-based and SCIAMACHY morning profiles. For both periods the agreement is very good between 15 and $22 \mathrm{~km}$ with relative differences having a slight positive bias and maximum value of $+6 \%$ in late winter/early 

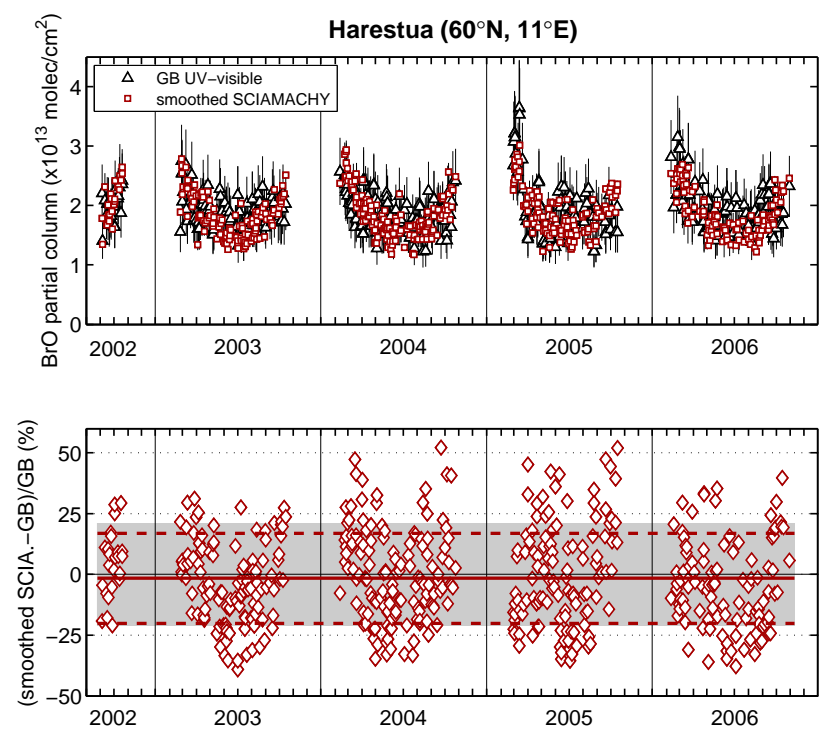

Fig. 11. Comparison of the $15-27 \mathrm{~km}$ BrO partial columns calculated from the smoothed SCIAMACHY limb and ground-based $\mathrm{UV}$-visible profiles at Harestua $\left(60^{\circ} \mathrm{N}, 11^{\circ} \mathrm{E}\right)$ for the $2002-2006$ period (morning coincidences). The relative differences appear on the lower plot. The error bars on the ground-based data correspond to the total error (systematic error + total retrieval error), estimated as in Hendrick et al. (2007). The solid and dashed red lines in the lower plot correspond to the mean relative difference and its onesigma standard deviation, respectively. The grey-shaded area indicates the mean uncertainty region for the ground-based UV-visible partial columns.

spring and a slight negative bias and maximum value of $-8 \%$ in late spring/summer/early fall. Above $21-22 \mathrm{~km}$, the ground-based retrieval gives larger $\mathrm{BrO}$ concentration values than SCIAMACHY with a maximum difference of about $-20 \%$ at $27 \mathrm{~km}$ for both late winter/early spring and late spring/summer/early fall periods. Comparison results for evening coincidences are depicted in Fig. 10. SCIAMACHY and ground-based profiles agree well, with SCIAMACHY smaller than ground-based by less than $6 \%$ between 18 and $27 \mathrm{~km}$ of altitude. The better agreement found for evening coincidences is most probably due to the fact that both SCIAMACHY and ground-based measurements are performed at almost the same local time. This minimizes the effect of possible dynamical fluctuations between both measurements and the impact on the agreement of the uncertainty in the photochemical correction applied to ground-based profiles is also expected to be smaller.

The BrO partial columns corresponding to morning and evening coincidences are presented in Figs. 11 and 12, respectively. Both morning and evening comparisons show that the SCIAMACHY and ground-based BrO columns are in good agreement, with, in average, SCIAMACHY lower than ground-based by $-2 \pm 19 \%$ and higher by $+4 \pm 13 \%$, respectively. The SCIAMACHY data are also generally within
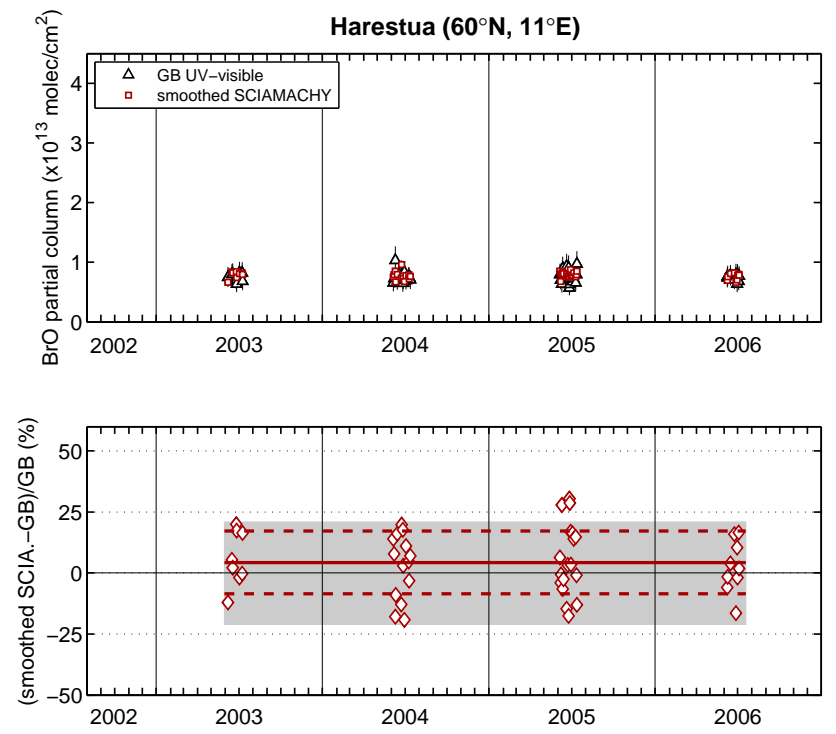

Fig. 12. Comparison of the $18-27 \mathrm{~km}$ BrO partial columns calculated from the smoothed SCIAMACHY limb and ground-based UV-visible profiles at Harestua $\left(60^{\circ} \mathrm{N}, 11^{\circ} \mathrm{E}\right)$ for the 2002-2006 period (evening coincidences). The relative differences appear on the lower plot. The error bars on the ground-based data correspond to the total error (systematic error + total retrieval error), estimated as in Hendrick et al. (2007). The solid and dashed red lines in the lower plot correspond to the mean relative difference and its onesigma standard deviation, respectively. The grey-shaded area indicates the mean uncertainty region for the ground-based UV-visible partial columns.

the error bars associated to the ground-based columns (corresponding to the total error), especially for evening conditions. The morning comparison displays similar features as at OHP and Lauder: (1) A seasonality in the relative difference, with a tendency to have more negative relative difference values in summer than during the rest of the year. As discussed in Sect. 5.1, this is most probably related to the uncertainty in the photochemical correction applied to groundbased profiles. Performing the same sensitivity tests as for OHP and Lauder, it is found that this uncertainty is larger at Harestua because of the presence of larger amount of $\mathrm{NO}_{2}$ in the stratosphere at $60^{\circ} \mathrm{N}$ than at mid-latitude. (2) The very good consistency in both data sets regarding the capture of the seasonality in the $\mathrm{BrO}$ column. Comparison results in late winter/early spring 2005 and 2006 also show that large $\mathrm{BrO}$ column values associated with bromine activation events are consistently detected by both instruments.

As for the OHP and Lauder comparisons, one should expect a negative bias of about $-10 \%$ in the comparison results if the same Wilmouth et al. (1999) BrO cross sections are used in both SCIAMACHY and ground-based UV-visible retrievals. This is illustrated in Fig. 13 where $15-27 \mathrm{~km} \mathrm{BrO}$ partial columns are compared for the year 2004 at Harestua using the Wilmouth et al. (1999) BrO cross sections in both 

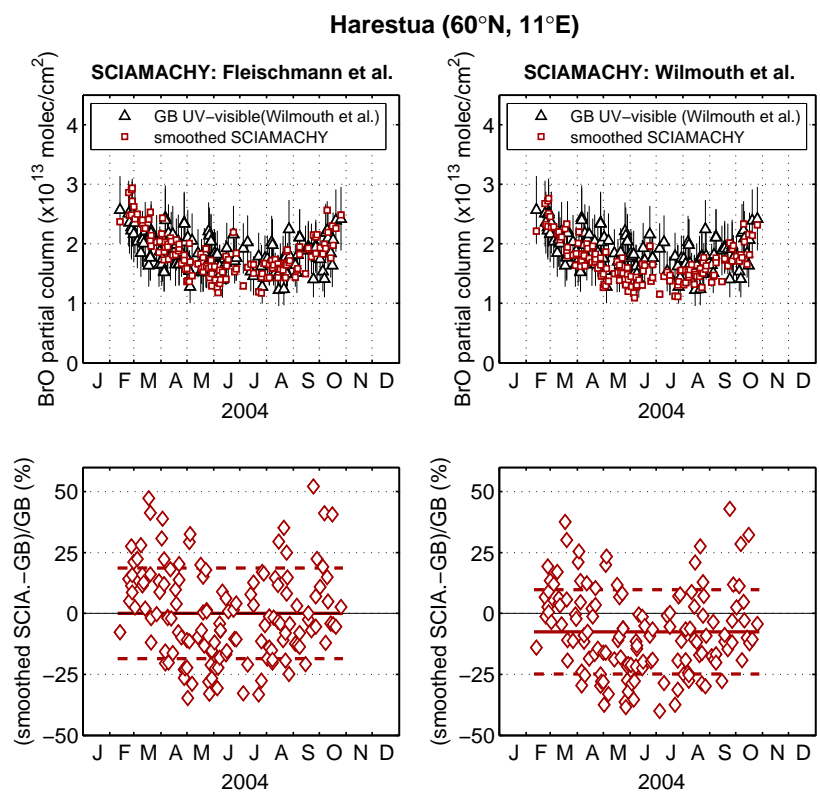

Fig. 13. Comparison of the $15-27 \mathrm{~km}$ BrO partial columns for the year 2004 at Harestua using the standard retrieval settings (left plots) and the same Wilmouth et al. (1999) BrO cross sections in both SCIAMACHY and ground-based retrievals (right plots). The relative differences appear in the lower plots. The error bars on the ground-based data correspond to the total error (systematic error + total retrieval error), estimated as in Hendrick et al. (2007). The solid and dashed red lines in the lower plots correspond to the mean relative difference and its one-sigma standard deviation, respectively.

retrievals. As can be seen, the relative difference are biased by $-8 \%$ in average compared to the case where the Fleischmann et al. (2004) and Wilmouth et al. (1999) are utilized in the SCIAMACHY and ground-based retrievals, respectively.

\section{Conclusions}

We have presented the results of the first multi-year comparison of stratospheric $\mathrm{BrO}$ profiles retrieved from SCIAMACHY limb (version 3.2 of the IUP Bremen scientific product) and ground-based UV-visible measurements performed over Harestua $\left(60^{\circ} \mathrm{N}\right)$, OHP $\left(44^{\circ} \mathrm{N}\right)$, and Lauder $\left(45^{\circ} \mathrm{S}\right)$ for the 2002-2006, 2005-2006, 2002-2005 periods, respectively. A comparison of the SCIAMACHY limb and ground-based UV-visible averaging kernels has shown that 15-27 km (morning coincidences) and 18-27 km (evening coincidences at Harestua) are the common altitude ranges where both retrievals display significant information content on the vertical distribution of BrO. A good agreement is found between SCIAMACHY limb and ground-based UVvisible partial columns calculated by integrating the retrieved profiles in the appropriate altitude range: at Harestua, SCIA-
MACHY is lower than the ground-based observations by $2 \pm 19 \%$ and higher by $4 \pm 13 \%$ on average for morning and evening coincidences, respectively. At OHP and Lauder (morning coincidences), SCIAMACHY is larger than the ground-based observations by $1 \pm 18 \%$ and $11 \pm 16 \%$, respectively. These comparison results are obtained, however, using different $\mathrm{BrO}$ cross sections in both retrievals. At the three stations, the relative difference between both data sets show a marked seasonal dependence, with a tendency to have SCIAMACHY generally larger than the ground-based observations in fall/winter/early spring and lower in late spring/summer. This seasonal dependence in the agreement is most probably caused by the stronger influence in summer of the photochemical correction applied to the ground-based profiles. Nevertheless, the seasonality on the BrO column is still consistently captured in both SCIAMACHY and groundbased UV-visible observations. Furthermore, large $\mathrm{BrO}$ columns associated with bromine activation events are simultaneously detected by both instruments in winter/early spring at Harestua. When comparing the mean vertical profiles, we have found a maximum difference of $23 \%$ between SCIAMACHY and ground-based UV-visible profiles. At OHP and Harestua, ground-based UV-visible retrievals give larger $\mathrm{BrO}$ concentration values than SCIAMACHY above $20-22 \mathrm{~km}$ while the opposite behaviour is found below $20 \mathrm{~km}$, except for Harestua in late spring/summer/early fall where groundbased UV-visible is larger than SCIAMACHY also in the 15$20 \mathrm{~km}$ altitude range. At Lauder, SCIAMACHY tends to be systematically larger than the ground-based observations between 15 and $27 \mathrm{~km}$.

In summary, this comparison study highlights the consistency and stability of the SCIAMACHY limb and groundbased UV-visible $\mathrm{BrO}$ profile retrievals and the capability to use these data sets for geophysical studies, i.e. for analyzing spatial and temporal variations of stratospheric $\mathrm{BrO}$.

Acknowledgements. This research was financially supported at IASB-BIRA by the Prodex contracts NOy-Bry and SECPEA and by the EC project GEOMON (6th Framework Program). IASBBIRA is also thankful to M. P. Chipperfield for providing the SLIMCAT data. The SCIAMACHY limb BrO retrieval activity was partially funded by the German Ministry of Education and Research (BMBF) through the German Aerospace Center (DLR) within the SADOS project (50EE0727). Some data shown here were calculated on German HLRN (High-Performance Computer Center North) and NIC/JUMP (Jülich Multiprocessor System). Services and support are gratefully acknowledged. The IUP Bremen group thanks also the European Centre for Medium-Range Weather Forecats (ECMWF) for providing the pressure, temperature, and surface elevation information (ECMWF Special Project SPDECDIO). NIWA authors thank the New Zealand Foundation for Research Science and Technology for long term support for the Lauder BrO measurements, and G. Mount, now at Washington State University, for the use on the Lauder BrO spectrometer (1995-2005), of a $-70^{\circ} \mathrm{C}$ cooled Reticon detector, that he developed at the NOAA Aeronomy Laboratory. 
Edited by: A. Piters

\section{References}

Aliwell, S. R., Van Roozendael, M., Johnston, P. V., Richter, A., Wagner, T., Arlander, D. W., Burrows, J. P., Fish, D. J., Jones, R. L., Tørnkvist, K. K., Lambert, J.-C., Pfeilsticker, K., and Pundt, I.: Analysis for $\mathrm{BrO}$ in zenith-sky spectra: An intercomparison exercise for analysis improvement, J. Geophys. Res., 107(D14), 4199, doi:10.1029/2001JD000329, 2002.

Bogumil, K., Orphal, J., Homann, T., Voigt, S., Spietz, P., Fleischmann, O. C., Vogel, A., Hartmann, M., Bovensmann, H., Frerik, J., and Burrows, J. P.: Measurements of molecular absorption spectra with the SCIAMACHY pre-flight model: instrument characterization and reference data for atmospheric remote sensing in the 230-2380 nm region, J. Photochem. Photobiol. A., 157, 167-184, doi:10.1016/S1010-6030(03)00062-5, 2003.

Bovensmann, H., Burrows, J. P., Buchwitz, M., Frerick, J., Noël, S., Rozanov, V. V., Chance, K. V., and Goede, A. H. P.: SCIAMACHY - Mission Objectives and Measurement Modes, J. Atmos. Sci., 56, 127-150, 1999.

Bracher, A., Sinnhuber, M., Rozanov, A., and Burrows, J. P.: Using a photochemical model for the validation of $\mathrm{NO}_{2}$ satellite measurements at different solar zenith angles, Atmos. Chem. Phys., 5, 393-408, 2005,

http://www.atmos-chem-phys.net/5/393/2005/.

Brinksma, E. J., Bracher, A., Lolkema, D. E., Segers, A. J., Boyd, I. S., Bramstedt, K., Claude, H., Godin-Beekmann, S., Hansen, G., Kopp, G., Leblanc, T., McDermid, I. S., Meijer, Y. J., Nakane, H., Parrish, A., von Savigny, C., Stebel, K., Swart, D. P. J., Taha, G., and Piters, A. J. M.: Geophysical validation of SCIAMACHY Limb Ozone Profiles, Atmos. Chem. Phys., 6, 197209, 2006,

http://www.atmos-chem-phys.net/6/197/2006/.

Butz, A., Bösch, H., Camy-Peyret, C., Chipperfield, M., Dorf, M., Dufour, G., Grunow, K., Jeseck, P., Kühl, S., Payan, S., Pepin, I., Pukite, J., Rozanov, A., von Savigny, C., Sioris, C., Wagner, T., Weidner, F., and Pfeilsticker, K.: Inter-comparison of stratospheric $\mathrm{O}_{3}$ and $\mathrm{NO}_{2}$ abundances retrieved from balloon borne direct sun observations and Envisat/SCIAMACHY limb measurements, Atmos. Chem. Phys., 6, 1293-1314, 2006, http://www.atmos-chem-phys.net/6/1293/2006/.

Connor, B. J., Siskind, D. E., Tsou, J. J., Parrish, A., and Remsberg, E. E.: Ground-based microwave observations of ozone in the upper stratosphere and mesosphere, J. Geophys. Res., 99(D8), 16757-16770, 1994.

Dorf, M., Bösch, H., Butz, A., Camy-Peyret, C., Chipperfield, M. P., Engel, A., Goutail, F., Grunow, K., Hendrick, F., Hrechanyy, S., Naujokat, B., Pommereau, J.-P., Van Roozendael, M., Sioris, C., Stroh, F., Weidner, F., and Pfeilsticker, K.: Balloonborne stratospheric BrO measurements: comparison with Envisat/SCIAMACHY BrO limb profiles, Atmos. Chem. Phys., 6, 2483-2501, 2006, http://www.atmos-chem-phys.net/6/2483/2006/.

Fish, D. J., Jones, R. L., and Strong, E. K.: Midlatitude observations of the diurnal variation of stratospheric BrO, J. Geophys. Res., 100(D9), 18863-18871, 1995.

Fleischmann, O. C., Hartmann, M., Burrows J. P., and Orphal, J.: New ultraviolet absorption cross-sections of $\mathrm{BrO}$ at atmospheric temperatures measured by time-windowing Fourier transform spectroscopy, J. Photochem. Photobiol. A, 168, 117-132, 2004.

Greenblatt, G. D., Orlando, J. J., Burkholder, J. B., and Ravishankara, A. R.: Absorption measurements of oxygen between 330 and 1140 nm, J. Geophys. Res., 95, 18577-18582, 1990.

Hendrick, F., Barret, B., Van Roozendael, M., Boesch, H., Butz, A., De Mazière, M., Goutail, F., Hermans, C., Lambert, J.-C., Pfeilsticker, K., and Pommereau, J.-P.: Retrieval of nitrogen dioxide stratospheric profiles from ground-based zenith-sky UVvisible observations: validation of the technique through correlative comparisons, Atmos. Chem. Phys., 4, 2091-2106, 2004, http://www.atmos-chem-phys.net/4/2091/2004/.

Hendrick, F., Van Roozendael, M., Chipperfield, M. P., Dorf, M., Goutail, F., Yang, X., Fayt, C., Hermans, C., Pfeilsticker, K., Pommereau, J.-P., Pyle, J. A., Theys, N., and De Mazière, M.: Retrieval of stratospheric and tropospheric BrO profiles and columns using ground-based zenith-sky DOAS observations at Harestua, 60 N, Atmos. Chem. Phys., 7, 4869-4885, 2007, http://www.atmos-chem-phys.net/7/4869/2007/.

Hendrick, F., Johnston, P. V., De Mazière, M., Fayt, C., Hermans, C., Kreher, K., Theys, N., Thomas, A., and Van Roozendael, M.: One-decade trend analysis of stratospheric $\mathrm{BrO}$ over Harestua $\left(60^{\circ} \mathrm{N}\right)$ and Lauder $\left(45^{\circ} \mathrm{S}\right)$ reveals a decline, Geophys. Res. Lett., 35, L14801, doi:10.1029/2008GL034154, 2008.

Kneizys, F. X., Shettle, E. P., Abreu, L. W., Chetwynd, J. H., Anderson, G. P., Gallery, W. O., Selby, J. E. A., and Clough, S. A.: Users Guide to LOWTRAN 7, Technical report, Air Force Geophysics Laboratory AFGL, 1986.

Kühl, S., Pukite, J., Deutschmann, T., Platt, U., and Wagner, T.: SCIAMACHY limb measurements of $\mathrm{NO}_{2}, \mathrm{BrO}$ and OClO. Retrieval of vertical profiles: Algorithm, first results, sensitivity and comparison studies, Adv. Space Res., 42(10), 1747-1764, 2008.

McLinden, C. A., McConnell, J. C., Griffioen, E., and McElroy, C. T.: A vector radiative transfer model for the Odin/OSIRIS project, Can. J. Phys., 80, 375-393, 2002.

Platt, U. and Stutz, J.: Differential Optical Absorption Spectroscopy (DOAS), Principles and Applications, ISBN 978-3-540-21193-8, Springer, Berlin Heidelberg, 2008.

Rodgers, C. D.: Inverse Methods for Atmospheric Sounding, Theory and Practice, World Scientific Publishing, SingaporeNewJersey-London-Hong Kong, 2000.

Rozanov, A., Bovensmann, H., Bracher, A., Hrechanyy, S., Rozanov, V., Sinnhuber, M., Stroh, F., and Burrows, J.: $\mathrm{NO}_{2}$ and $\mathrm{BrO}$ vertical profiles retrieval from SCIAMACHY limb measurements: Sensitivity studies, Adv. Space Res., 36, 846-854, doi:10.1016/j.asr.2005.03.013, 2005a.

Rozanov, A., Rozanov, V., Buchwitz, M., Kokhanovsky, A., and Burrows, J. P.: SCIATRAN 2.0 - A new radiative transfer model for geophysical applications in the $175-2400 \mathrm{~nm}$ spectral region, Adv. Space Res., 36, 1015-1019, doi:10.1016/j.asr.2005.03.012, $2005 b$.

Rozanov, A., Eichmann, K.-U., von Savigny, C., Bovensmann, H., Burrows, J. P., von Bargen, A., Doicu, A., Hilgers, S., GodinBeekmann, S., Leblanc, T., and McDermid, I. S.: Comparison of the inversion algorithms applied to the ozone vertical profile retrieval from SCIAMACHY limb measurements, Atmos. Chem. Phys., 7, 4763-4779, 2007, http://www.atmos-chem-phys.net/7/4763/2007/.

Schofield, R., Kreher, K., Connor, B. J., Johnston, P. V., Thomas, 
A., Shooter, D., Chipperfield, M. P., Rodgers, C. D., and Mount, G. H.: Retrieved tropospheric and stratospheric BrO columns over Lauder, New Zealand, J. Geophys. Res., 109, D14304, doi:10.1029/2003JD004463, 2004.

Sheode, N., Sinnhuber, B.-M., Rozanov, A., and Burrows, J. P.: Towards a climatology of stratospheric bromine monoxide from SCIAMACHY limb observations, Atmos. Chem. Phys. Discuss., 6, 6431-6466, 2006, http://www.atmos-chem-phys-discuss.net/6/6431/2006/.

Sinnhuber, B.-M., Rozanov, A., Sheode, N., Afe, O. T., Richter, A., Sinnhuber, M., Wittrock, F., Burrows, J. P., Stiller, G. P., von Clarmann, T., and Linden, A.: Global observations of stratospheric bromine monoxide from SCIAMACHY, Geophys. Res. Lett., 32, L20810, doi:10.129/2005GL023839, 2005.

Sioris, C. E., Kovalenko, L. J., McLinden, C. A., Salawitch, R. J., Van Roozendael, M., Goutail, F., Dorf, M., Pfeilsticker, K., Chance, K., von Savigny, C., Liu, X., Kurosu, T. P., Pommereau, J.-P., Bösch, H., and Frerick, J.: Latitudinal and vertical distribution of bromine monoxide in the lower stratosphere from Scanning Imaging Absorption Spectrometer for Atmospheric Chartography limb scattering measurements, J. Geophys. Res., 111, D14301, doi:10.1029/2005JD006479, 2006.
Theys, N., Van Roozendael, M., Hendrick, F., Fayt, C., Hermans, C., Baray, J.-L., Goutail, F., Pommereau, J.-P., and De Mazière, M.: Retrieval of stratospheric and tropospheric $\mathrm{BrO}$ columns from multi-axis DOAS measurements at Reunion Island $\left(21^{\circ} \mathrm{S}\right.$, $56^{\circ}$ E), Atmos. Chem. Phys., 7, 4733-4749, 2007,

http://www.atmos-chem-phys.net/7/4733/2007/.

von Savigny, C., Rozanov, A., Bovensmann, H., Eichmann, K.-U., Noel, S., Rozanov, V. V., Sinnhuber, B.-M., Weber, M., Burrows, J. P., and Kaiser, J. W.: The ozone hole break-up in September 2002 as seen by SCIAMACHY on ENVISAT, J. Atmos. Sci., 62, 721-734, doi:10.1175/JAS-3328.1, 2005.

Wamsley, P. R., Elkins, J. W., Fahey, D. W., et al.: Distribution of halon-1211 in the upper troposphere and lower stratosphere and the 1994 total bromine budget, J. Geophys. Res., 103, 15131526, 1998

Wilmouth, D. M., Hanisco, T. F., Donahue, N. M., and Anderson, J. G.: Fourier transform ultraviolet spectroscopy of the $\mathrm{A}\left({ }^{2} \Pi_{3 / 2}\right) \leftarrow \mathrm{X}\left({ }^{2} \Pi_{3 / 2}\right)$ transition of $\mathrm{BrO}$, J. Phys. Chem., 103, 8935-8945, 1999. 